\title{
Weddell seal observations on female and pup behavior and breeding status for four overwintering periods (2015 to 2018) at Barton Peninsula, King George Island, Antarctica
}

\author{
Yejin Kim ${ }^{1,2}$, In-Young $\mathrm{Ahn}^{3}$, Ji Kang Park ${ }^{1}$, Won Young Lee ${ }^{1 *}$

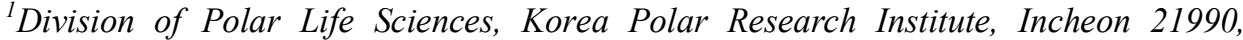 \\ Republic of Korea \\ ${ }^{2}$ Department of Life Science, Ewha Womans University, Seoul 03760, Republic of Korea \\ ${ }^{3}$ Division of Polar Ocean Sciences, Korea Polar Research Institute, Incheon 21990, \\ Republic of Korea
}

\begin{abstract}
In animal ecology studies, it is a fundamental monitoring work to observe annual breeding cycle. In this study, we report the detailed observations on seven mother and pup pairs of Weddell seal (Leptonychotes weddellii) at Barton peninsula, King George Island, Antarctica. Two or three pairs had been observed along the coast on the fast ice in 2015, 2017, and 2018 and no breeding was recorded in 2016. Although it varied among individuals, pups were recorded to be born on 19-25 Sept., began swimming at day 18-19 after birth, and molted at day 21-25. Our observations may provide fundamental breeding information of Weddell seals in our study site and contribute to the future longterm monitoring research of seals.
\end{abstract}

Key words: annual breeding cycle, Leptonychotes weddellii, Barton Peninsula, Antarctica

DOI: $10.5817 / \mathrm{CPR} 2020-1-1$

\section{Introduction}

In Antarctic ecosystem, seals are important key species to monitor the effects of rapid environmental changes ongoing in Antarctic pinnipedian mammal populations. Weddell seals (Leptonychotes weddellii) are one of the largest pinniped species distributed around Antarctica (Shirihai et al. 2008), from sub-Antarctic Islands, such as South Georgia (Burton 2015), to the Antarctic continent (Cameron and Siniff 2004).
Territorial males defend their territories and communicate with females by vocalization through ice (Thomas et al. 1988, Terhune 2017). After mating, the female individuals give birth to one pup on the fast ice that is anchored to the shore, from Sept. to Nov. and twins are rarely observed (Stirling 1969, Wu et al. 2018). It was previously reported that the female seals raise their newborn pups up to 6-7 weeks after the birth (Reijnders et al. 1990). During the

Received May 4, 2020, accepted June 15, 2020.

*Corresponding author: wonyounglee@kopri.re.kr Acknowledgements: We are grateful to the overwintering crew members at the King Sejong station from 2015 to 2018 for their dedicated fieldwork. This study was supported by Korea Polar Research Institute (PE20110). 
lactating period, maternal feeding in the sea is not performed (Reijnders et al. 1990). Seal pups start swimming within two weeks after their birth and the initial coat is shedded after 44 days of their lives, taking about 17 days (Shirihai et al. 2008). Then, the young seals stop feeding on their mother's milk at about 50-55 days after birth (Shirihai et al. 2008). Weddell pups have high individual variations in vocal sounds for maternal recognition (Van Opzeeland et al. 2012)

It is important to observe annual breeding cycle for seal studies and provide information on their role in ecosystem as a top predator. Reproduction cycles are basic for breeding biology and enables us to understand the population dynamics (Siniff et al. 1977) and even contribute to build a conservation plan for endangered species with the focus on their survival (Johanos et al. 1994). Previous reports on Weddell seal breeding have been mostly conducted from a specific research base, McMurdo station of the US, near the McMurdo Sound (Stirling 1969, Testa and Siniff 1987, Cameron and Siniff 2004). It requires a long-term monitoring with regular observations from

\section{Material and Methods}

All observations were conducted at near the King Sejong station located in Barton Peninsula, one of the ice-free sectors of King George island (Fig. 1). In 2015, Sept. to Nov., 16 winter crew members carried out observations of Weddell seals everyday near the station area. Also, research team went around the Barton peninsula along the coast at least once a week for taking biological sample and animal observation. In 2016, 2017, and 2018, 17 winter members did the similar fieldwork. Especially in 2018, a biology researcher patrolled around the station 6 times per day on average.

When individual seals were encountered, each female and pup were recorded the Antarctic winter season and therefore not many studies have been reported from other regions (except of Salwicka and Rakusa-Suszczewski 2002). For breeding survey of seals, it is necessary to conduct daily observations to get profound information of post-partum behavior of Weddell seals; for instance, lactating duration and time to begin swimming.

In this study, we aimed to conduct fundamental observations on breeding ecology of Weddell seals near the King Sejong station (Korean station, $62^{\circ} 14^{\prime} \mathrm{S}, 58^{\circ} 46^{\prime} \mathrm{W}$, Barton Peninsula, King George Island, Antarctica). From 2015 to 2018, during the wintering period, our overwintering crew members conducted the detailed field observations and recorded the breeding schedule of Weddell seals. Thus, we could describe the breeding schedule after birth up to 24 days. To our best knowledge, this is the first report of their breeding behavior at near birth periods in the study area. Despite the small sample size, it may give detailed breeding information on pupping date schedules and breeding success before the independence of pups is reached.

and photographed by handy digital cameras. Individuals were identified by their feather patterns on their body spots. The exact birth dates were determined when the pups were newly found with the females and confirmed by checking dryness of umbilical cords. Their breeding status was categorized into three behavioral activities of main breeding events since the birth: lactating, swimming, and molting. Observations of the seals were logged or recorded until they left the study area. All the field records were daily submitted to the station directors and the collected field notes and photographs were used for this study. 

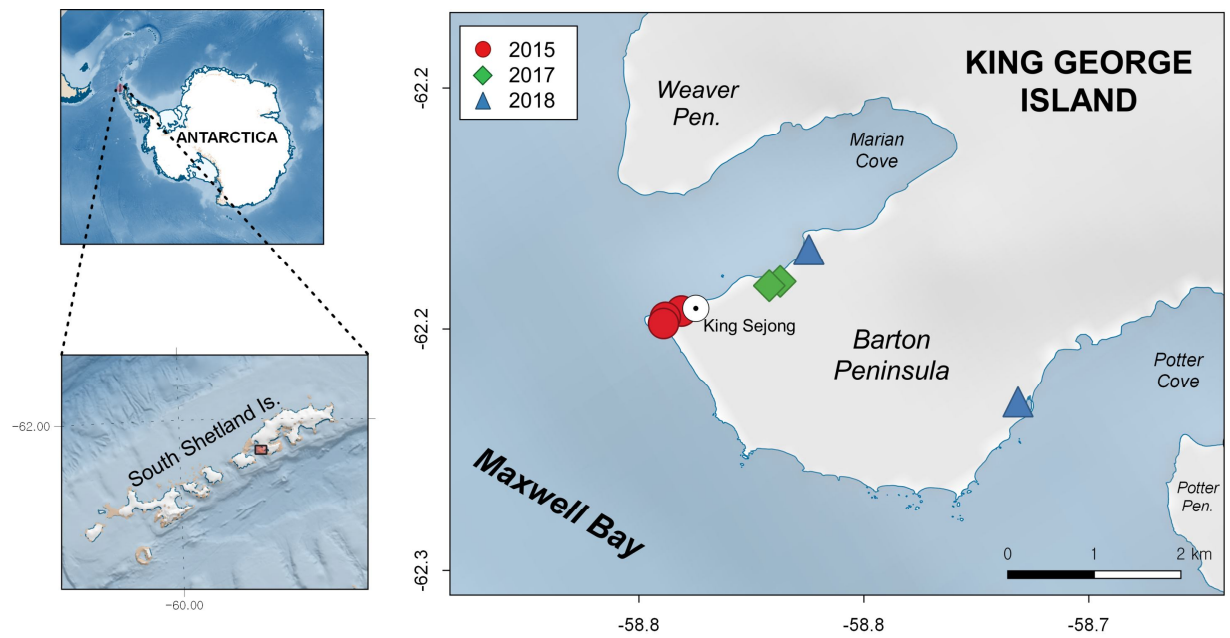

Fig. 1. Map of the study area (King Sejong Station at Barton Peninsula, King George Island, Antarctica). Symbols represent the sighting locations of the Weddell seal female-pup pairs.

\section{Results and Discussion}

In Sept. and Oct. from 2015 to 2018, total 7 mother-pup pairs of Weddell seals were recorded on the fast ice along the coast of Barton Peninsula (Fig. 1). Three pairs in 2015, none in 2016, two in 2017, and two in 2018 were observed. All observed females gave birth to one pup. In 2016, there were nobreeding records found around this area. According to the statements of the overwintering members, there were little sea ice in Maxwell Bay in that year unlike other years. We think that the sea ice condition could be considered to explain the non-breeding event. Although satellite evidence is not supported in this study, such low sea ice distribution based on the direct observation from the coast areas in 2016 implies that breeding attempts of the Weddell seals could be negatively affected by reduction of the fast ice. The summarized information on observed main breeding events and the abbreviation of breeding pairs and pups is presented in Table 1.

\begin{tabular}{|c|c|c|c|c|c|}
\hline \multirow[b]{2}{*}{ Year } & \multirow[b]{2}{*}{ Family ID } & \multicolumn{4}{|c|}{ Main breeding events and the observed periods } \\
\hline & & $\begin{array}{l}\text { Birth } \\
\text { of pup }\end{array}$ & $\begin{array}{l}\text { Lactation by } \\
\text { mother }\end{array}$ & $\begin{array}{c}\text { Swimming } \\
\text { of pup }\end{array}$ & $\begin{array}{c}\text { Molting } \\
\text { of pup }\end{array}$ \\
\hline \multirow{3}{*}{2015} & ID 1 & 19 Sept. & 19 Sept. - 26 Sept. & - & - \\
\hline & ID 2 & 25 Sept. & 25 Sept. -22 Oct. & 12 Oct. -20 Oct. & 15 Oct. -22 Oct. \\
\hline & ID $3 \dagger$ & 24 Sept. & 26 Sept. -27 Oct. & 14 Oct. -23 Oct. & 20 Oct. -27 Oct. \\
\hline \multirow{2}{*}{2017} & ID 4 & 22 Sept. & 24 Sept. & - & - \\
\hline & ID 5 & 23 Sept. & 25 Sept. & - & - \\
\hline \multirow{2}{*}{2018} & ID 6 & 25 Sept. & 25 Sept. & - & - \\
\hline & ID 7 & 20 Sept. & 30 Sept. & - & - \\
\hline
\end{tabular}

Table 1. Summary of observed main breeding events of Weddell seals at Barton peninsula, King George Island, Antarctica from 2015 to 2018 (no breeding records in 2016). Note: $\dagger$ ID3 pup was found dead on 27 Oct. 2015. 
In 2015, three cases were observed right in front of the station. ID1 pup was found in neonate at first on 19 Sept. and then no longer observed after blizzard on 27 Sept. ID2 pup was born on 25 Sept. (Fig. 2 in upper left) and the umbilical cord had been observed by day 12 after birth (Fig. 2 in upper right). It started swimming from 12 Oct. (Fig. 2, in lower left) and the change in its fur color around its eyelids was identified

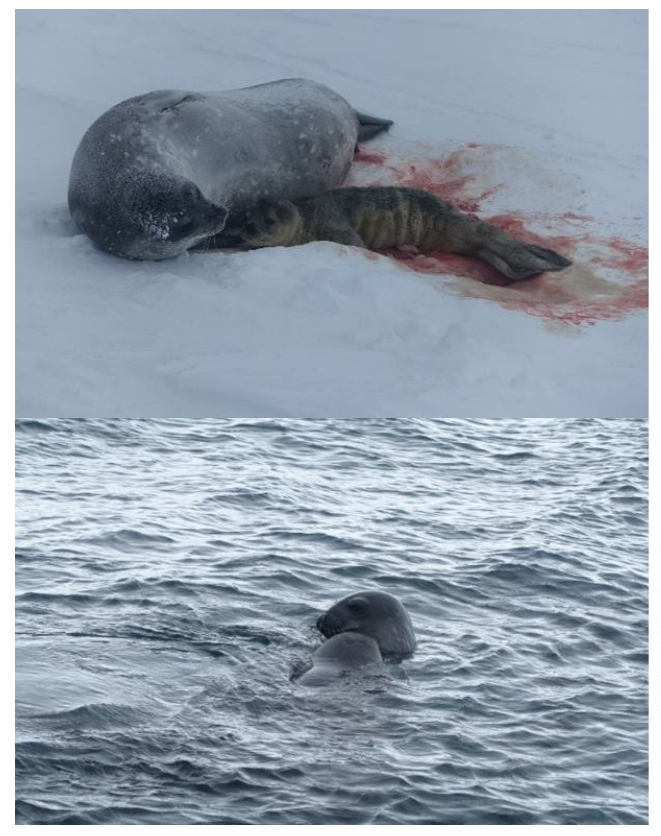

on 15 Oct. Since 22 Oct., ID2 family had not been observed. ID3 pup was estimated to be born on 24 Sept., and it was observed to swim with its mother from day 21 (14 Oct.) and molt from 20 Oct. (Fig. 2 in lower right). The pup was found dead on 27 Oct. with unknown reason and its mother had wandered around her cub for seven days after the pup death and then left the site.

Fig. 2. Photograph records revealing main breeding events of Weddell seals during our study period. A female and a newborn Weddell seal on 27 September, 2015 (ID2, in upper left) which undried umbilical cord had been observed by day 12 after birth on 6 October (in upper right), and their swimming behavior was first observed at day 18 on 15 October (in lower left). Molt was initiated from the head and the flippers of a seal pup at day 21 in October $14^{\text {th }}$ in 2015 (ID3, in lower right).

No breeding records were found in 2016 and two pairs were seen in 2017 and 2018. They were observed by crew members patrolling along the coast of the Barton Peninsula, approximately $1 \mathrm{~km}$ away from the station in 2017 (ID 4 and 5) and $1.5 \mathrm{~km}$ and $3 \mathrm{~km}$ away in 2018 (ID 6 and 7, respectively). Early breeding periods includ-

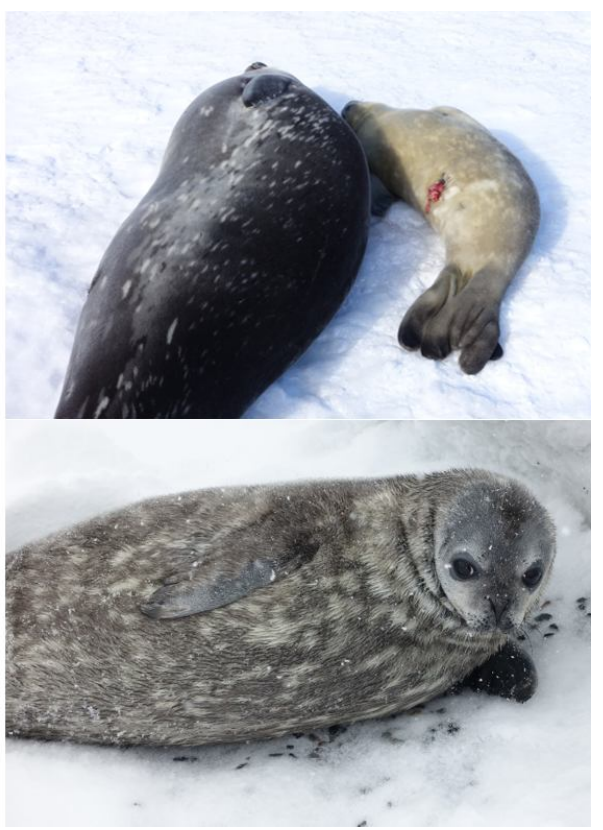


neonates were observed from 5 Sept. to 2 Oct. in 1978 (Myrcha and Teliga 1980) and in the Vestfold Hills in Long Fjord $\left(68^{\circ} 32^{\prime} \mathrm{S}, 78^{\circ} 14^{\prime} \mathrm{E}\right)$ from 1 Oct. during 1994-1995 (Lake et al. 1997). The breeding dates seem to be relatively earlier than those of other previous results observed in southern areas at Erebus Bay $\left(77^{\circ} 40^{\prime} \mathrm{S}\right.$, $167^{\circ} 6^{\prime} \mathrm{E}$ ), birth dates of seal pups ranged from 10 Oct. to 22 Nov., during 2005-2007 (Proffitt et al. 2010). The other data report breeding period from 10 Oct. to 23 Nov. in the Drescher Inlet $\left(72^{\circ} 52^{\prime} \mathrm{S}, 19^{\circ} 25^{\prime} \mathrm{W}\right)$ in 1986 (Reijnders et al. 1990). We expect that such differences of pupping dates by regions could be related to the latitudes (Shirihai et al. 2006, Stirling 1969), possibly with the delayed starts of Antarctic summer in the far southern areas.

In conclusion, our observations showed breeding periods of Weddell seals at Barton Peninsula and contribute to the future stud- ies on behavioral ecology of seals in this area. For accurate identification of seals, it would be helpful to use individual tags on the seals that may provide better understanding for the post-partum behavior of Weddell seals. In the South Shetland Islands, Weddell seal studies were conducted on diet analyses at King George Island (Lipinski and Woyciechowski 1981, Barrera-Oro and Marschoff 1990, Casaux et al. 1997, Daneri et al. 2000), at Deception Islands (Clarke and MacLeod 1982), and at Livingston Islands (Barrera-Oro and Marschoff 1990, Acevedo et al. 2015). To our best knowledge, there has been the only one study on Weddell seal breeding surveys in this region done by a Polish research group from 1988 to 2000 (Salwicka and Rukusa-Suszczewski 2002). A longterm monitoring research would be required with regular fieldworks for the detailed behavioral studies.

\section{References}

Acevedo, J., Carreño, J., Torres, D. Aguayo-Lobo, A. and Letelier, S. (2015): Cephalopod remains in scats of Weddell seals (Leptonychotes weddellii) at Cape Sheriff, South Shetland Islands, Antarctica. Polar Biology, 38(9): 1559-1564. doi:10.1007/s00300-015-1713-0

BARRERA-Oro, E., MARschoff, E. (1990): A declining trend in the abundance of Notothenia rossii and Notothenia gibberifrons observed in fjords in two sites in the South Shetland Islands. Commission for the Conservation of Antarctic Marine Living Resources, Fish Stock Assessment Working Group, Selected Scientific Papers: 263-273.

Burton, R. (2015): The Weddell seals of Larsen Harbour, South Georgia: A unique but apparently declining colony. Polar Records, 51(6): 667-671. doi:10.1017/S0032247414000953

Cameron, M. F., Siniff, D. B. (2004): Age-specific survival, abundance, and immigration rates of a Weddell seal (Leptonychotes weddellii) population in McMurdo Sound, Antarctica. Canadian Journal of Zoology, 82(4): 601-615. doi:10.1139/z04-025

Casaux, R., Baroni, A. and CARlini, A. (1997): The diet of the Weddell seal Leptonychotes weddellii at harmony point, South Shetland Islands. Polar Biology, 18: 371-375. doi: $10.1007 / \mathrm{s} 003000050202$

Clarke, M., MacLeod, N. (1982): Cephalopod remains in the stomachs of eight Weddell seals. British Antarctic Survey Bulletin, 57: 33-40.

Daneri, G. A., Carlini, A. R. and Rodhouse, P. G. K. (2000): Cephalopod diet of the southern elephant seal, Mirounga leonina, at King George Island, South Shetland Islands. Antarctic Science, 12(1): 16-19. doi:10.1017/S0954102000000031

Johanos, T. C., Becker, B. L. and Ragen, T. J. (1994): Annual reproductive cycle of the female Hawaiian monk seal (Monachus schauinslandi). Marine Mammal Science, 10: 13-30. doi: 10.1111/j.1748-7692.1994.tb00386.x 
Y. KIM et al.

Lake, S. E., Burton, H. R. and Hindell, M. A. (1997): Influence of time of day and month on Weddell seal haul-out patterns at the Vestfold Hills, Antarctica. Polar Biology, 18(5): 319-324. doi:10.1007/s003000050194

LIPINSKI, M., WoycIECHOWSKI, M. (1981): Cephalopods in the food of Weddell seals from the Admiralty Bay (King George Island, South Shetland Islands). Polish Polar Research, 2: 163167.

Myrcha, A., Teliga, K. (1980): Observations of pinnipedian mammals in the vicinity of Arctowski Station (King George Island) in 1978. Polish Polar Research, 117-126.

Proffitt, K. M., Rotella, J. J. and Garrott, R. A. (2010): Effects of pup age, maternal age, and birth date on pre-weaning survival rates of Weddell seals in Erebus Bay, Antarctica. Oikos, 119(8): 1255-1264. doi:10.1111/j.1600-0706.2009.18098.x

ReIJNDERS, P. J. H., PlÖtZ, J., ZeGERS, J. and GRÄFE, M. (1990): Breeding biology of weddell seals (Leptonychotes weddellii) at Drescher Inlet, riiser larsen ice shelf, Antarctica. Polar Biology, 10(4): 301-306. doi:10.1007/BF00238429

SALWICKA, K., RAKUSA-SUSZCZEWSKI, S. (2002): Long-term monitoring of Antarctic pinnipeds in Admiralty Bay (South Shetlands, Antarctica). Acta Theriologica, 47(4): 443-457. doi:10.1007/ BF03192469

Shirihai, H., Jarrett, B., Cox, J. and Kirwan, G. M. (2008): The complete guide to Antarctic wildlife: birds and marine mammals of the Antarctic continent and the Southern Ocean $\left(2^{\text {nd }}\right.$ ed.). Princeton: Princeton University Press, pp. 348-350.

Shirihai, H., JARRETt, B. and KirWAN, G. M. (2006): Whales, dolphins, and other marine mammals of the world. Princeton, N.J.: Princeton University Press, 384 p.

Siniff, D. B., DeMaster, D. P., Hofman, R. J. and Eberhardt, L. L. (1977): An analysis of the dynamics of a Weddell seal population. Ecological Monographs, 47(3): 319-335. doi:10.2307/ 1942520

StiRLing, I. (1969): Ecology of the Weddell seal in McMurdo Sound, Antarctica. Ecology, 50(4): 573-586. doi:10.2307/1936247

Terhune, J. M. (2017): Through-ice communication by Weddell seals (Leptonychotes weddellii) is possible. Polar Biology, 40: 2133-2136. doi:10.1007/s00300-017-2124-1

Testa, J. W., SinifF, D. B. (1987): Population Dynamics of Weddell Seals (Leptonychotes Weddelli) in McMurdo Sound, Antarctica. Ecological Monographs, 57(2): 149-165. doi: $10.2307 / 1942622$

Thomas, J. A., Puddicombe, R. A., George, M. and Lewis, D. (1988): Variations in underwater vocalization of Weddell seals (Leptonychotes weddellii) at the Vestfold Hills as a measure of breeding population discreteness. Hydrobiologia, 165: 279-284.

Van Opzeeland, I. C., Van Parijs, S.M., Frickenhaus, S. Kreiss, C. M. and Boebel, O. (2012): Individual variation in pup vocalizations and absence of behavioral signs of maternal vocal recognition in Weddell seals (Leptonychotes weddellii). Marine Mammal Science, 28: 158-172. doi:10.1111/j.1748-7692.2011.00505.x

Wu, F. X., Zhang, Z. W., MiaO, X., Dai, Y. F., Wang, X. Y. and Zhu, Q. (2018): Three cases of potential twinning in Weddell seals (Leptonychotes weddellii) at Fildes Peninsula, King George Island, Antarctica. Polar Biology, 41(4): 611-617. doi:10.1007/s00300-017-2222-0 